\title{
Peran Keteladanan Guru Sosiologi Dalam Membentuk Karakter Sosial Siswa di SMAN 1 Sape
}

\author{
Irfan \\ Program Studi Pendidikan Sosiologi STKIP Bima \\ Jalan Piere Tendean Kel. Mande Tlp.Fax (0374) 42801, Bima 84191, Indonesia \\ email; irfanfagih@gmail.com
}

\begin{abstract}
Abstrak
Pembentukan karakter sosial peserta didik kunci utamanya adalah adanya keteladanan dari seorang guru yang bisa mempengaruhi sikap, sifat dan perilaku dalam aktifitasnya dilingkungan sekolah maupun lingkungan masyarakat. Keteladanan yang utama ketika anak berada di sekolah adalah guru harus memberikan contoh yang baik. Guru sebagai salah satu ujung tombak character building mempunyai peranan penting, karena guru merupakan sosok terdepan dalam mengawal perubahan karakter bangsa ini di masa yang akan datang. Guru harus tetap menjadi orang yang harus digugu dan ditiru. Hal ini karena sebagai seorang pendidik, guru menjadi sosok figur dalam pandangan anak, sehingga guru akan menjadi patokan bagi sikap peserta didik.

Berdasarkan hasil pengamatan awal peneliti di SMAN 1 Sape dijumpai peserta didik yang kurang memiliki karakter baik, cukup banyak peserta didik yang melawan perintah guru, melanggar tata tertib yang berlaku, suka bolos sekolah, berkata kasar, kurang sopan pada yang lebih tua serta suka berkelahi, khususunya di kelas kelas XI. Meskipun guru sudah memberikan segala macam cara dan mencontohkan perilaku-perilaku yang baik seperti disiplin masuk sekolah, berpakaian rapi, tetapi pada kenyataannya masih banyak peserta didik yang belum meneladaninya. Hal ini menandakan kurang maksimlanya peran keteladanan yang ditunjukkan oleh guru-guru pada peserta didik. Adapun rumusan masalah dalam penelitian ini adalah bagaimanakah peran keteladanan guru sosiologi dalam pembentukan karakter sosial siswa di SMAN 1 Sape Tahun Pembelajaran 2018/2019. Sedangkan metode yang digunakan dalam penelitian ini adalah metode pendekatan kualitatif dengan jenis deskriptif. Hasil penelitian ini menunjukan bahwa guru memberikan keteladan dengan cara menanamkan nilai-nilai karakter seperti: nilai religius, disiplin, kejujuran, kerjasama, patuh pada aturan sosial, santun, demokrastis dan tanggung jawab sosial. Metode yang digunakan dalam mengintegrasikan nilai-nilai karakter adalah dengan menerapkan metode sopan santun, keteladanan, penegakkan kedisipinan, pembiasan dan integritas nilai-nilai karakter dalam kegiatan ektrakurikuler dan intrakurikuler.
\end{abstract}

Kata Kunci : Keteladanan, Guru Sosiologi, Karakter Sosial Siswa. 


\section{Pendahuluan}

Pembentukan karakter peserta didik merupakan komitmen kolektif lembaga pendidikan menghadapi tuntutan global dewasa ini. Sebagai perwujudan dari komitmen tersebut, dibuatlah undangundang Republik Indonesia Nomor 20 Tahun 2006 tentang Sistem Pendidikan Nasional Pasal 3 yang menjelaskan bahwa "pendidikan nasional berfungsi mengembangkan kemampuan dan membentuk watak serta peradaban bangsa yang bermartabat dalam rangka mencerdaskan kehidupan bangsa, bertujuan untuk berkembangnya potensi peserta didik agar menjadi manusia yang beriman dan bertakwa kepada Tuhan Yang Maha Esa, berakhlak mulia, sehat, berilmu, cakap, kreatif, mandiri, dan menjadi warga negara yang demokratis serta bertanggung jawab.”

Cita-cita luhur bangsa sebagai mana tertuang dalam tujuan pendidikan nasional tersebut adalah perwujudan nilai moral bangsa yang harus tertanam dan mengakar dalam pola hidup berbangsa, bernegara, dan bermasyarakat. Oleh karena itu, pembentukan karakter menjadi bagian yang tak terpisahkan dengan pola pembinaan, baik yang dilakukan dalam rumah tangga, masyarakat, dan sekolah sebagai pioneer yang paling berperan dalam pembentukan karakter atau watak anak. Pembentukan dan pendidikan karakter tersebut, tidak akan berhasil selama antar lingkungan pendidikan tidak ada kesinambungan dan keharmonisan. Dengan demikian, rumah tangga dan keluarga sebagai lingkungan pembentukan dan pendidikan karakter pertama dan utama harus lebih diberdayakan.

Namun, perkembangan teknologi
informasi dan komunikasi yang
berkembang melalui media cetak dan
elektronik seolah telah mengambil alih
fungsi-fungsi pendidikan orang tua,
masyarakat, dan guru. Arus global yang

bergerak begitu cepat melalui media Internet yang serba digital telah berhasil mengubah paradigma, pola dan gaya hidup, dan bahkan tata nilai, sikap dan prilaku yang berdampak pada menipisnya sendi-sendi moral dan akhlak anak bangsa yang berimbas pada memudarnya karakter bangsa.

Keteladanan yang ditanamkan oleh para pendiri bangsa semakin lama semakin menipis, mulai dari memudarnya keteladanan para pemimpin, tokoh masyarakat, orang tua, dan bahkan guru sebagai pengemban utama pendidikan formal di sekolah. Realitas memudarnya nilai-nilai keteladanan guru dapat ditunjukkan dengan hasil temuan Komisi Perlindungan Anak Indonesia (KPAI) menemukan bahwa kekerasan terhadap anak yang dilakukan oleh tenaga pendidik atau guru menunjukkan hasil yang cenrung semakin tinggi dari waktu ke waktu. Kekerasan guru terhadap murid dapat ditinjau dari empat dimensi, yakni (1) kekerasan verbal, (2) kekerasan fisik, (3) kekerasan psikologis, (4) kekerasan yang berkaitan dengan profesionalisme, (Amir, 2009:30).

Kekerasan verbal mencakup
penggunaan stereotip-stereotip dan
penamaan yang bermuatan seksi, rasis, kultur, dan sosio-ekonomi. Kekerasan fisik meliputi tindakan mendorong, mencubit, menjambuk, menjewer, memukul dengan penggaris, atau melemparkan sesuatu. Kekerasan psikologis terjadi melalui tindakan berteriak, berbicara dengan kasar, menyobek hasil kerja, mengadu domba siswa, dan membuat ancaman-ancaman. Sedangkan, kekerasan yang berkaitan dengan profesionalisme dapat terjadi melalui penilaian yang tidak adil, menerapkan hukuman dengan pilih kasih, menggunakan cara-cara pendisiplinan yang tidak pantas, mengarahkan pada kegagalan dengan menetapkan standar 
yang tidak wajar, mengambil kesempatan dengan menggunakan materi-materi atau pengayaan, mengintimidasi orang tua karena hambatan bahasa, budaya, atau status sosial ekonomi.

Dalam membentuk karakter peserta didik, kunci utamanya ada pada keteladanan. Keteladanan yang utama ketika anak berada di sekolah adalah guru. Guru sebagai salah satu ujung tombak character building mempunyai peranan penting, karena guru merupakan sosok terdepan dalam mengawal perubahan karakter bangsa ini di masa yang akan datang. Guru harus tetap menjadi orang yang harus digugu dan ditiru. Hal ini karena sebagai seorang pendidik, guru menjadi sosok figur dalam pandangan anak, sehingga guru akan menjadi patokan bagi sikap peserta didik.

Beberapa kasus dijumpai, guru mempunyai kepribadian yang tidak baik, seperti guru yang bersikap kasar kepada murid, labelling negatif terhadap anak, ataupun perbuatan asusila yang dilakukan oleh seorang guru terhadap murid. Ketika kondisi - kondisi demikian dialami anak, sangat dimungkinkan anak mengalami trauma. Dampak selanjutnya, anak dapat bersikap negatif terhadap diri sendiri maupun kepada orang lain. Dengan kepribadian yang tidak sesuai dengan norma- norma tersebut seorang guru tidak akan mendapat tempat dalam penilaian siswa sehingga guru tidak dihargai dan akhirnya akan menjadi model yang buruk bagi siswa.

Berdasarkan hasil pengamatan awal peneliti di SMAN 1 Sape dijumpai peserta didik yang kurang memiliki karakter baik, cukup banyak peserta didik yang melawan perintah guru, melanggar tata tertib yang berlaku, suka bolos sekolah, suka tawuran, berkata kasar, kurang sopan pada yang lebih tua serta suka berkelahi, khususunya di kelas kelas X SMAN 1 Sape masih dijumpai beberapa peserta didik yang kurang sopan, tidak disiplin, suka berkelahi, melawan perintah guru dan tidak rapi dalam berpenampilan. Meskipun guru sudah memberikan segala macam cara dan mencontohkan perilaku-perilaku yang baik seperti disiplin masuk sekolah, berpakaian rapi, tetapi pada kenyataan masih banyak peserta didik yang belum meneladaninya. Hal ini menandakan kurang maksimlanya peran keteladanan yang ditunjukkan oleh guru-guru pada peserta didik.

Guru adalah pihak yang berhubungan langsung dengan peserta didik dalam praktik pendidikan. Maka guru merupakan ujung tombak dari program pendidikan karakter di lembagalembaga pendidikan. Seorang guru haruslah mempunyai karakter positif yang kuat agar mampu membentuk karakter siswa. Karakter positif guru sering disebut dengan sikap professional guru. Di lapangan masih banyak guru yang belum menyadari peranan mereka sebagai ujung tombak dalam program pembentukan karakter siswa di sekolah. Guru tersebut tidak memberi contoh ataupun teladan yang baik bagi siswanya.

Berangkat dari permasalahan di atas, penulis ingin mengkaji pentingnya keteladanan pendidik dalam membentuk karakter peserta didik, maka dengan ini penulis mengangkat judul: "Peran Keteladanan Guru Sosiologi Dalam membentuk Karakter Sosial Siswa di SMAN 1 Sape Tahun Pembelajaran 2018/2019." 


\section{Tinjauan Pustaka}

1. Keteladanan Guru

Dalam Kamus Besar Bahasa Indonesia disebutkan, bahwa keteladanan berasal dari kata dasar teladan yang artinya sesuatu (perbuatan, barang dsb,) yang patut ditiru atau dicontoh ( Poerwadarminta, 2007: 1036). Jadi keteladanan adalah hal-hal yang dapat ditiru atau dicontoh. Keteladanan guru adalah sikap dan tingkah laku guru, ucapan maupun perbuatan yang sifatnya mendidik, dapat ditiru dan diteladani oleh anak didiknya. Keteladanan merupakan faktor yang sangat penting untuk membentuk sikap baik atau buruknya pada anak didik. Setiap anak didik mengidamkan memiliki sosok figur yang mempunyai sifat yang ideal sebagi sumber keteladanan yang dapat dijadikan pedoman dalam kehidupannya. Dalam pendidikan guru adalah salah satu sosok figur yang dapat dijadikan contoh bagi anak didiknya, ketika guru mampu menampilkan keteladanan yang baik tentu saja hal itu akan menjadi salah satu motivasi bagi anak didik untuk bersikap lebih baik.

2. Pembentukan Karakter Siswa

Secara umum karakter diartikan sebagai perilaku yang dilandasi oleh nilai-nilai berdasarkan norma agama, kebudayaan, hukum/konstitusi, adat istiadat, dan estetika.Wynne mengemukakan bahwa karakter berasal dari bahasa Yunani yang berarti "to mark" (menandai) dan memfokuskan pada bagaimana menerapkan nilai-nilai kebaikan dalam tindakan nyata atau perilaku sehari-hari. Menurutnya ada dua pengertian karakter. Pertama, menunjukkan pada bagaimana seseorang bertingkah laku. Kedua istilah karakter erat kaitannya dengan personality. Seseorang baru bisa disebut sebagai orang yang berkarakter apabila tingkah lakunya sesuai kaidah moral, (Mulyasa, 2011:59).

Karakter siswa adalah kepribadian yang menjadikan tipikal dalam cara berfikir dan bertindak yang melekat pada diri seseorang. Karakter siswa terdiri atas tiga unjuk perilaku terdiri atas pengetahuan moral, perasaan berlandaskan moral, dan perilaku berlandaskan moral. Karakter yang baik terdiri atas proses tahu di mana yang baik, keinginan melakukan yang baik, dan melakukan yang baik.

\section{Metode Penelitian}

Penelitian ini bersifat kualitatif, data yang dianalisis berbentuk diskriptif, sehingga data yang terkumpul berupa katakata. Sebagaimana menurut Lexi Moleong bahwa: "Penelitian kualitatif adalah penelitian yang bermaksud untuk memahami fenomena yang dialami oleh subyek penelitian, misalnya perilaku, peresepsi, motivasi, tindakan, dan lainlain, secara holistik dan dengan cara deskripsi dalam bentuk kata-kata dan bahasa, pada suatu konteks khusus yang alamiah memanfaatkan berbagai metode ilmiah. (Moleong, 2009: 6).

Sedangkan penelitian deskriptif menurut Whitney adalah pencarian fakta dengan interpretasi yang tepat. (Nazir, 2005 : 54). Penelitin deskriptif mempelajari masalah-masalah dalam masyarakat, serta tata cara yang berlaku dalam masyarakat dengan situasi-situasi tertentu, termasuk tentang hubungan, kegiatan-kegiatan, sikap-sikap, pandanganpandangan, serta proses-proses yang sedang berlangsung dan pengaruhpengaruh dari situasi fenomenologi. Penelitian ini berupaya mendeskripsikan dan sekaligus memberikan penjelasan mengenai peran keteladanan guru dalam membentuk karakter sosial siswa di SMAN 1 Sape

Adapun informan pertama atau informan kunci (key informan) dalam penelitian ini adalah guru mata pelajaran 
sosiologi yang berjumlah 3 (orang). Sedangkan yang menjadi informan dalam penelitian ini adalah kepala sekolah, wakasek dan siswa kelas XI, XII di SMAN 1 Sape.

\section{Hasil Penelitian}

Adapun hasil penelitian tentang Peran Keteladanan guru sosiologi dalam membentuk karakter sosial siswa di SMAN 1 Sape Tahun Pembelajaran 2018/2019 adalah sebagai berikut:

1. Guru Sosiologi Menerapkan Metode Sopan Santun Pada Seluruh Siswa baik pada saat jam pelajaran maupun diluar jam pelajaran.

Perilaku akhlak mulia siswa tercermin dari sifat mulianya yakni sopan santun. Mereka sopan santun dalam berkata-kata, dalam pergaulan antara sesama teman dan juga terhadap gurunya. Keadaan prilaku itu sudah tercermin pada siswa SMA Negeri 1 Sape, ditambah lagi dengan kebijakan dari sekolah agar siswanya berprilaku yang baik sesuai visi-misi sekolah. Penerapan metode sopan santun disekolah rutin dilakukan oleh segenap guru di SMAN 1 Sape, baik pada saat kegiatan belajar mengajar di kelas maupun diluar kelas. Didalam kelas misalnya guru selalu menyampaikan materi dengan bahasa yang lemah lembut, mudah dimengerti dan selalu menyelipkan nilai-nilai ahlak yang mulia pada setiap materi yang diajarkan. Sehingga Peserta didik memperoleh pengetahuan dari gurunya agar lebih banyak mencontoh sebagai sosok panutan, yang memiliki nilai moral dan agama, nilai-nilai karakter dan akhlak, yang patut ditiru oleh anak didik. Contoh atau keteladanan seperti ini lebih merupakan aspek sikap dan perilaku, budi pekerti luhur dan akhlak mulia, seperti disiplin, lemah lembut, sopan santun terhadap sesama.

Dalam bertutur kata sebaiknya dijaga, apalagi saat bersama saudara, sahabat atau yang lainnya, semua orang sangat menyukai orang yang sopan dalam berbicara dan yang lebih penting lagi adalah keramahan. Misalnya: "selalu menggunakan katakata yang sopan dalam setiap berucap dan berinteraksi baik dengan guru maupun sesama siswa.

2. Guru Sosiologi Menerapkan Metode Keteladanan Kepada Seluruh siswa pada setiap kegiatan sekolah.

Metode teladan yang dilakukan di SMAN 1 Sape merupakan salah satu langkah penanaman akhlak dan pembentukan karakter siswa. Sifat lemah lembut baik yang dilakukan di kelas ataupun di luar pembelajaran sebagai kegiatan untuk memberikan pengetahuan tentang nilai-nilai karakter yang baik. Peserta didik diharapkan mampu memberikan nilai akhlak yang baik dan berusaha untuk menghindari hal-hal yang dilarang.

Pembentukan karakter siswa yang dilakukan guru adalah agar peserta didik memahami dan mengetahui tentang akhlak yang baik, diarahkan, dimotivasi dan didorong untuk mengamalkan akhlak yang baik agar menjadi suatu kebiasaan dalam kehidupan sehari-hari. Selain itu, pembentukan karakter dan penanaman nilai-nilai karakter kepada siswa diawalai dari Masa Orientasi Siswa di sekolah, pada saat itulah seorang guru bisa memperkenalkan peraturan dan tanggung jawab siswa disekolah.

Seperti yang kita tau bahwa pada masa orientasi inilah siswa akan mulai berfikir sehingga menjadi tau apa yang harus dilakukan. Selebihnya dari itu, tugas tugas dari kakak panitia yang semakin membuat siswa itu mulai latihan dan berlatih untuk mentaati peraturan dan menjalankkan tanggung jawabnya, mulai dari disiplin dan sebagainya. Dengan adanya kepanitian ini juga bisa menjadikan jembatan untuk memperkenalkan, melatih, 
memotivasi, bisa menjaga dan mendampingi adik-adiknya untuk berkreasi dan belajar mengenal lebih jauh terhadap lingkungan sekolah.

Dalam hal ini diharapkan kepada siswa-siswi yang senior dapat membaur bersama siswa baru tidak terbatas pada waktu dan tempat, karena dengan demikian antara siswada guruguru bisa memberikan contoh suri tauladan mulai dari mempraktekkan yang baik dan benar, pribahasa antara siswa dengan guru dan siswa dengan siswa, begitu juga bagaimana bersikap guru dengan siswa begitu juga sebaliknya, sehingga siswa akan berusaha menjaga dan melatih diri untuk lebih baik.

Suritauladan yang benar sesuai dengan konsep Islam adalah memberikan contoh bukan memberikan arahan dan teguran saja, akan tetapi yang terpenting adalah beranngkat dari dseorang guru itu sendiri yang kemudian dijadikan contoh untuk siswanya baik dari cara berkomunikasi atau bertutur kata. yang baik dan sopan. Dalam hal ini Komunikasi dan tuturkata perlu dijaga, karena dalam pepatah mengatakan, tergelincirnya kaki itu lebih selamat dari pada tergelincirnya lisan, maka dari itu sangat penting bagi seorang guru untuk selalu menjaga tutur kata dari dirinya sendiri kemudian untuk menegur dan memberikan arahan bagaimana bertuturkata yang baik, baik untuk teman sebaya disekolah maupun dilingkungannya dimana iya tinggal, lebih-lebih terhadap guru dan orang tua di rumah.

3. Guru Sosiologi Menerapkan Metode Penegakkan Kedisiplinan pada setiap yang kedapatan melanggar tata tertib sekolah.

Kedisiplinan merupakan kepatuhan untuk menghormati dan melaksanakan suatu sistem yang mengharuskan orang untuk tunduk kepada keputusan, perintah dan peraturan yang berlaku. Artinya Seorang guru harus selalu mengingatkan, menegur dan memberi peringatan kepada siswa bahwa hal yang demikian itu tidak baik, sudah jelas bahwa suri tauladan yang baik dan menjadi seorang guru yang bijaksana juga tidak langsung memberikan konsekuensi kepada siswa melainkan terlebih dahulu memberikan nasehat, berupa teguran, peringatan hingga menuntun kepada yang seharusnya siswa lakukan tentunya diarahkan kepada hal yang baik.

Salah satu bentuk penegakan kedisiplinan yang dilakukan guru sosiologi terhadap siswa yang melanggar adalah dengan memberikan hukuman yang sesuai dengan tingkat kesalahan yang dilanggar, salah satunya ketika ada siswa yang kedapatan melanggar seperti tidak disiplin dilingkungan sekolah misalnya menempatkan buku di perpustakaaan yang telah dibaca bukan pada tempatnya, maka awalnya diberi peringatan dan kemudian memberikan hukuman berupa merapikan semua buku yang telah dibacanya serta teman-temanya yang lain.

Selanjutnya sebagai guru yang selalu diguguh dan ditiru, maka selayaknya seorang guru dalam mengajarkan siswanya diawalai dari dirinya sendiri, sehingga bisa ditiru oleh siswanya, dalam konsep suri tauladan yang baik itu adalah bukan serta merta memerintahkan siswanya untuk berbuat dan melakukan sesuatu, akan tetapi seorang guru lebih tepat untuk memberikan contoh kemudian mengajak siswanya untuk menirukan dirinya. Misalnya ketika ada salah satu siswa di SMAN I Sape yang kedapatan melanggar peraturan yang ada ditempat ibadah, maka ada konsekuensinya hukuman yang diberikan, yang pertama diingatkan, yang kedua diberi nasehat yang ketiga diberi hukuman 
seperti membersihkan Wc/tempat wudhue, kalau dia masih melanggar, dikasih tau kalau sekolah kamu itu tidak pantas di sekolah ini, dengan demikian siswa akan malu dengan dirinya sendiri, dan dengan seperti itu dia akan sadar dengan sendirinya.

4. Guru Sosiologi Menerapkan Metode Pembiasaan terhadap hal-hal yang baik seperti senyum, sapa dan salam dalam berinteraksi dengan siswa.

Pertama, guru-guru menerapkan 3 $\mathrm{S}$ (senyum, sapa dan salam). Pembentukan karakter dimulai sejak pagi hari, misalnya siswa ketemu dengan guru lalu salam, kemudian Salam dan Sapa terhadap gurunya.

Kebiasaan 3S ini dimulai sejak siswa itu datang ke sekolah di pagi hari sampai mereka pulang meninggalkan sekolah. Para guru yang khususnya ada jam mengajar di pagi hari atau guru yang bertepatan mendapatkan jadwal piket, sebelum bel jam masuk pelajaran pagi harus berdiri di depan pintu gerbang untuk menerapkan $3 \mathrm{~S}$ (senyum, sapa dan salam). Budaya 3S ini diterapkan dalam upaya pembentukan karakter siswa di SMAN 1 Sape. Dan peran guru sosiologi sangat dibutuhkan dalam membentuk karakter siswa tersebut.

Pembentukan karakter siswa perlu diwujudkan dalam lingkungan keluarga, masyarakat dan sekolah secara berkesinambungan. Pelaksanaan pendidikan karakter di sekolah perlu didukung oleh peran keluarga khususnya orang tua juga peran masyarakat atau lingkungan sekitar dimana tempat siswa itu tinggal.

Sekolah sebagai pelaksana pendidikan formal perlu memperhatikan elemen-elemen yang ada di dalamnya dalam mengintegrasikan semua aspek untuk membina karakter siswanya. Bukan semata dari segi akademiknya, namun dimensi akhlak dan karakter merupakan hal yang utama. Percuma saja jika sekolah setiap tahun meluluskan lulusan yang IQ nya di atas rata-rata namun tidak dibarengi dengan karakter yang baik dan akhlak yang mulia. Karena sudah banyak orang pintar di masyarakat bahkan di negara kita yang tidak memiliki karakter yang baik sehingga perbuatannya merugikan dirinya sendiri, masyarakat bahkan merugikan negara.

Kedua, melaksanakan programprogram keagamaan dan ibadah rutin. program yang bisa membentuk karakter siswa SMAN 1 Sape, diantaranya shalat dhuha tiap pagi yang diikuti semua siswa dan para guru. Kemudian mengaji yasinan yang dilaksanakan pada hari jum eat. Membaca surat-surat pendek setiap hari rabu dan hari kamis serta shalat dzuhur berjamah setiap hari yang diikuti seluruh siswa dan guru. Disini tidak hanya guru sosiologi yang berperan, namun melibatkan semua guru. Karena siswa secara tidak langsung meneladani gurunya.

Dari beberapa yang ditambahkan oleh informan di atas, penulis menyimpulkan bahwa strategi-strategi yang diterapkan baik oleh guru sosiologi khususnya maupun sekolah pada umumnya sudah mengupayakan sekuat tenaga untuk menanamkan nilainilai yang Islami seperti shalat dhuha, shalat dzuhur berjamaah, yasinan, membaca surat-surat pendek dan lainlain. Diharapkan dari program-program tersebut walaupun sifatnya sedikit paksaan untuk siswa, namun dengan paksaan tersebut akan berubah menjadi kebiasaan. Sehingga yang tadinya siswa itu terpaksa melakukan shalat dhuha contohnya, kemudian karena keharusan dan terus menerus (continue) maka akan sendirinya berubah menjadi kebiasaan yang jika tidak melaksanakan perbuatan tersebut akan merasa tidak 
enak atau sesuatu yang mengganjal di hati siswa.

Penulis bisa menyimpulkan bahwa, disekolah ini selain melakukan pembiasaan yang sifatnya umum seperti 3S kemudian kegiatan kegiatan yang lain, pembiasaan nilai-nilai karakter ini sangatlah penting untuk generasi muslim saat ini, tanpa disadari keyakinan dan pengetahuan terhadap nilai-nilai keislaman semakin menipis, jadi sangat menarik sekali ketika sekolah berbau umum bisa mengedepan kegiatan-kegiatan keislaman.

5. Guru Sosiologi Menerapkan Metode Integritas terhadap rangkaian kegiatan siswa baik yang bersifat intrakurikuler maupun ekstrakurikuler.

Pembentukan karakter siswa di SMA Negeri 1 Sape, tidak serta merta berdiri sendiri, melainkan terintegrasi ke dalam kegiatan intrakurikuler dan ekstrakurikuler. Pembentukan karakter secara terintegrasi dalam mata pelajaran adalah pengenalan nilai-nilai, diperolehnya kesadaran akan pentingnya nilai-nilai, dan penginternalisasian nilai-nilai karakter ke dalam tingkah laku peserta didik. Pertama, dalam kegiatan kepramukaan, melalui kegiatan ekstra ini juga anak-anak diajarkan bagaimana mencintai lingkungan, yang dalam hal ini melalui kegiatan pramuka untuk melestarikan lingkungan sekolah diadakannya lomba keindahan kelas. Melalui kegiatan ektrakulikuler kepramukaan diselipkan nilai-nilai karakter, salah satunya adalah yang tertera dalam kode etik ayat kedua yang berbunyi cinta alam dan kasih sayang kepada sesama manusia.

Kedua, Bentuk integrasi pendidikan karakter bangsa ke dalam mata pelajaran sosiologi di SMA Negeri 1 Sape tersebut melalui proses pembelajaran, baik yang berlangsung di dalam kelas maupun pembelajaran yang dilakukan di luar kelas pada semua mata pelajaran. Pengintegrasian tersebut dilakukan dengan cara memasukan nilai-nilai pendidikan karakter ke dalam kompetensi dasar (KD). Jumlah kompetensi dasar disetiap mata pelajaran yang dapat diintegrasikan nilai-nilai karakter tentu berbeda. Kompetensi dasar yang yang dapat diintegrasikan nilai-nilai pendidikan karakter tersebut dikembangkan pada silabus dan rencana pelaksanaan pembelajaran (RPP). Materi pembelajaran yang berkaitan dengan norma atau nilai-nilai pada setiap mata pelajaran perlu dikembangkan dan dikaitkan dengan konteks kehidupan sehari-hari. Penanaman nilai-nilai karakter tidak hanya pada ranah kognitif, tetapi lebih menyentuh pada internalisasi dan pengalaman nyata dalam kehidupan peserta didik sehari-hari di masyarakat. Selain itu, pada mata pelajaran sosiologi guru mengintegrasikan nilainilai pendidikan karakter seperti bersahabat, komunikasitif, cinta damai, peduli sosial, peduli lingkungan, religius, toleransi, disiplin kerja keras, kreatif, demokratis, dan rasa ingin tahu.

Dalam konteks pendidikan, ada banyak nilai pendidikan karakter yang perlu ditanamkan dalam dada tiap siswa. Nilai-nilai itu adalah religius, yaitu sikap dan perilaku patuh melaksanakan ajaran agama, toleran terhadap agama lain, dan sikap hidup rukun dengan pemeluk agama lain. Jujur, yaitu perilaku yang mendasarkan pada upaya menjadikan dirinya sebagai orang selalu bisa dipercaya dalam perkataan dan perbuatan. 


\section{Kesimpulan}

Peran keteladanan guru sosiologi dalam pembentukan karakter sosial siswa di SMAN 1 Sape Tahun Pembelajaran 2018/2019, dilakukan dengan cara menanamkan nilai-nilai karakter seperti: nilai religius, disiplin, kejujuran, kerjasama, patuh pada aturan sosial, santun, demokrastis dan tanggung jawab sosial. Metode yang digunakan dalam mengintegrasikan nilai-nilai karakter adalah metode sopan santun, metode keteladanan, penegakkan kedisipinan, pembiasan dan metode integritas nilai-nilai karakter dalam kegiatan ektrakurikuler dan intrakurikuler. Pembentukan akhlak siswa yang dilakukan guru adalah agar peserta didik memahami dan mengetahui tentang akhlak yang baik, diarahkan, dimotivasi dan didorong untuk mengamalkan akhlak yang baik agar menjadi suatu kebiasaan dalam kehidupan sehari-hari. Berdasarkan penelitian yang di lakukan penulis, di temukan bahwa penanaman akhlak siswa di SMA Negeri 1 Sape di lakukan melalui sebagai berikut:lemah lembut, disiplin, sopan santun, saling tolong menolong, tutur kata dan berpakaian seragam.

\section{Daftar Pustaka}

Ahmad, Usman, 2008. Mari Belajar

Meneliti. Yogyakarta. Genta Press

Amir Tengku Ramly, 2009. Menjadi Guru

Bintang, Cet. I: Bekasi : Pustaka Inti

Anis Matta, Muhammad, 2005.

Membentuk Karakter Cara Islami.

Jakarta: Al-I'tishom Cahaya Umat

Arikunto, 2006. Prosedur Penelitian Suatu

Pendekatan Praktik. Jakarta. Rineka Cipta

Aqib, Zainal, 2011. Menjadi Guru yang

Sukses dan Berpangaruh. Elba Fitrah

Depdiknas, 2003. Sistem Pendidikan

Nasional. Depdiknas. Jakarta

Dharma Kesuma, 2010. Pendidikan

Karakter: Strategi Mendidik Anak di

Zaman Global. Jakarta: Grasindo
Edi Waluyo, 2007. Pendidikan Moral dan

Budi Pekerti dalam Perspektif

Perubahan: Menggagas Platform

Pendidikan Budi Pekerti Secara

Kontekstual dan Futuristik. Jakarta: Bumi Aksara

Fauzil, 2006. Positive Parenting: Caracara Islami Mengembangkan Karakter Positif Pada Anak Anda. Bandung: Al Mizan

Isa, 2004. Pengembangan Profesi Guru.

Bandung. Alfabeta

Mansyur, 2008. Menggugat Pendidikan

Indonesia. Yogyakarta: Ar-Ruz Media.

Mulyasa, E, 2011. Manajemen Pendidikan

Karakter. Jakarta: Bumi Aksara.

Munir, Abdullah, 2010. Pendidikan Karakter (Membangun Karakter Anak Sejak dari Rumah). Yogyakarta: Pedagogia

Peraturan Pemerintah No 19 Tahun 2005. Standar Nasional Pendidikan. Jakarta Poerwadarminta, 2007. Kamus Besar Bahasa Indonesia. Jakarta. Rineka Cipta

Riduwan, 2009. Belajar Mudah Penelitian. Alfabeta. Bandung

Sukardi, 2008. Metodologi Penelitian Pendidikan. Jakarta. Bumi Aksara

Sugiyono, 2009. Statistik untuk Penelitian. Bandung. Alfabeta

Sukmadinata, 2010. Metode Penelitian Pendidikan. Bandung . Rosda Karya

Suryabrata, 2006. Psikologi Pembelajaran dan Pengajaran. Bandung. Tarsito

Suyanto dan Djihad Hisyam, 2005. Standar Kompetensi dan Sertifikasi Guru. Bandung: Remaja Rosdakarya Syah, 2009. Psikologi Pendidikan dengan Pendekatan Baru. Bandung. Rosda Karya

Tasrif, 2011. Pengantar Profesi Keguruan. Kurnia Kalam Semesta. Jogjakarta

Zainal dan Sujak, 2011. Pendidikan Karakter Perspektif Islam. Bandung: PT Remaja Rosdakarya

Zubaedi, 2011. Pendidikan Karakter.

Bandung: PT Remaja Rosdakarya. 